\title{
O estável poder de veto Forças Armadas sobre o tema da anistia política no Brasil ${ }^{*}$
}

\section{The stable military power as veto players in issues related to the political amnesty in Brazil}

\author{
MARIA CELINA D'ARAUJO \\ Professora do Departamento de Sociologia e Política \\ Pontifícia Universidade Católica do Rio de Janeiro - PUC-Rio. \\ Rua Marquês de São Vicente, 225, Gávea - Rio de Janeiro \\ CEP 22451-900 - Rio de Janeiro - RJ \\ mariacelina@daraujo.net
}

RESUMO $O$ trabalho propõe-se a demonstrar porque desde 1979 foi possível aos militares brasileiros atuarem como veto players sempre que entrou em debate a revisão da Lei de Anistia. Nossa hipótese é que esse poder de veto explica-se pela existência de uma grande autonomia militar antes, durante e depois da ditadura, associada aos baixos níveis de respeito aos direitos humanos na sociedade brasileira e ao baixo interesse do Congresso e do governo em geral pelo tema das Forças Armadas.

Palavras-chave anistia, forças armadas, transição no Brasil

ABSTRACT The study aims to show why since 1979 the Brazilian military had been able to act as veto players whenever the debate about Amnesty Law was argued. Our hypothesis is that this veto power is explained by the existence

*Artigo recebido em 20/08/2012. Autor convidado. 
of a large military autonomy before, during and after the dictatorship, associated with low levels of human rights culture in Brazilian society and the low interest of Congress and government in general about Armed Forces issues.

Keywords amnesty, armed forces, transition in Brazil

\section{Introdução}

Por que negar a evidente necessidade da memória? Pergunta do personagem feminino no filme Hiroshima, meu amor de Alain Resnais, 1979, ao se referir aos horrores provocados pela bomba atômica.

Uma das questões mais delicadas para transição brasileira, a exemplo de outros países, foi o tratamento a ser dado aos agentes do Estado que praticaram ações tipificadas, já nessa época, como crimes contra a humanidade. ${ }^{1} 0$ Brasil não foi original quando optou por uma "anistia recíproca”, aprovada em lei pelo Congresso Nacional em 1979, ainda durante a ditadura (1964-1985). Essa foi uma anistia negociada com a oposição, que contemplava crimes e transgressões cometidos pelos adversários do regime, mas também os agentes estatais responsáveis pelas práticas de tortura, mortes e desaparecimentos. ${ }^{2}$ Desde então, as Forças Armadas do Brasil têm se valido dessa decisão para revidar qualquer iniciativa que vise punir aqueles que praticaram crimes contra a humanidade durante o regime militar (1964-1985). A lei de 1979, segundo os militares e grande parte da sociedade brasileira, teria sentenciado uma única possibilidade de interpretação da história.

O Brasil não foi, assim, o único país a aprovar uma anistia desse teor em momentos de transição para a democracia. Muito menos foi o único em que fortes reações aconteceram, quando se tratou de levar a cabo julgamentos de crimes contra os direitos humanos praticados durante a ditadura. No entanto, é o país em que os agentes do Estado envolvidos com esses crimes tiveram mais sucesso como veto players quando se tratou de rever o período à luz de novos dados e de novas perspectivas políticas, humanas ou jurídicas. A peculiaridade do país se deve ao fato de ser, até meados de 2012, o único país da

\footnotetext{
Declaração Universal dos Direitos Humanos, ONU, 1947.

2 Lembre-se que apesar das negociações, a lei foi aprovada por pequena margem. Grande parte da oposição demandava punição para os torturadores. Ver a esse respeito SOUSA, Jessie Jane Vieira de. Anistia no Brasil: um processo político em disputa. In: COMISSÃO DE ANISTIA. A anistia na era da responsabilização: o Brasil em perspectiva internacional e comparada. Brasília/Oxford: Ministério da Justiça, Comissão de Anistia/Oxford University, Latin American Centre, 2011, p. 188-210.
} 
América Latina em que nenhum militar ou policial envolvido com esses crimes chegou ao banco dos réus. ${ }^{3}$

A partir desta constatação, o trabalho propõe-se a demonstrar que o sucesso dos militares como veto players na questão do julgamento dos crimes contra a humanidade está relacionado ao tipo de relações civil-militares construída no país. A impunidade tem a ver também com a cultura de direitos humanos existente numa sociedade. No Brasil, os direitos humanos são um tema emergente e um valor em construção. Essa realidade, combinada a uma tradição de autonomia militar, criou o pior cenário para a responsabilização individual dos crimes praticados durante os governos de exceção, e até mesmo nas questões criminais sem cunho político.

Nossa hipótese é que a existência de uma grande autonomia militar antes, durante e depois da ditadura, associada aos baixos níveis de respeito aos direitos humanos na sociedade brasileira, e ao baixo interesse do Congresso e do governo em geral pelo tema das Forças Armadas, garantiram espaços para que a corporação militar atuasse como veto player sempre que se tentou rediscutir ou rever a Lei da Anistia de 1979 ou algumas prerrogativas da corporação.

\section{Anistia política num entorno de baixa cultura de direitos humanos}

Parte-se da premissa de que desde 1979 as Forças Armadas fizeram da Lei da Anistia um assunto tabu e atuaram com poder de veto sempre que o tema entrou na agenda política. Contaram para tanto, com o apoio velado ou explícito do Poder Executivo, com a morosidade da Justiça, a inapetência do Legislativo para com os temas dos militares e dos direitos humanos. Tiveram a seu favor, especialmente, o fato de que a sociedade brasileira nunca se mobilizou em defesa de uma política de direitos.

Para abordar este aspecto, comecemos com um dado fornecido pelo IPEA, Instituto de Pesquisa Econômico Aplicada, uma das mais respeitáveis instituições de pesquisa do país. ${ }^{4}$ Dados desse Instituto, divulgados em janeiro de 2012, em meio aos debates sobre a criação da Comissão da Verdade, informavam que $42,9 \%$ dos brasileiros nunca tinham ouvido falar na Lei de Anistia, $31,9 \%$ ouviram falar, mas não sabiam do que se tratava, e apenas $24,3 \%$ sabiam o seu conteúdo. Entre estes, as diferenças são grandes quando se leva

3 Em abril de 2010, a Lei de Anistia foi declarada constitucional pelo STF, ou seja, não permitiria julgamentos.

4 IPEA. Sistema de Indicadores de Percepção Social. SIPS Defesa Nacional (2012) disponível on line. http://www. ipea.gov.br/. Acesso em: 20 ago. 2012. 
em conta os níveis educacionais: apenas $18,7 \%$ para quem tinha até quatro anos de escolaridade; $24,3 \%$ quando a escolaridade subia dois ou três anos; e $46,9 \%$ para quem tinha superior, completo ou incompleto, ou pós-graduação. ${ }^{5}$ Mesmo considerando que o Brasil tem aumentando consistentemente o nível educacional da população, segundos dados oficiais, apenas $8 \%$ dos brasileiros têm nível superior. Assim, mesmo entre esta minoria educada, não chega a $50 \%$ o percentual daqueles que dizem conhecer ou saber do que se trata a Lei de Anistia.

Para este grupo de $24,3 \%$ de pessoas que dizia saber do que se tratava a Lei de Anistia, foi feita uma pergunta sobre a possibilidade de a Lei ser revista, para que pudesse haver investigação e punição de crimes cometidos durante o regime militar. Neste aspecto o resultado é também significativo, para refletirmos sobre a importância da opinião da sociedade em temas como direitos humanos e justiça: $33,4 \%$ disseram que deveria haver investigação e punição para todos os envolvidos nos crimes praticados durante a ditadura; $22,2 \%$ achavam que deveria haver investigação e punição apenas para os agentes da repressão; 20,3\% opinavam que não deviria haver qualquer investigação; $11,8 \%$ que deveria haver investigação sem punição para ninguém; 11,4\% que deveria haver investigação e punição apenas para os que participaram de grupos de oposição armada.

Em suma, entre os $24,3 \%$ informados sobre a Lei de Anistia, apenas 22,2\% concordaram com a possibilidade de investigação e punição apenas para os agentes da repressão. Parte expressiva (em torno de 45\%) incluiria a oposição armada entre aqueles a serem investigados e passíveis de punição. De outra parte, cerca de $32 \%$ não queriam qualquer investigação e se houvesse, não queriam qualquer punição.

Ainda na embocadura do entorno social, pesquisa divulgada em junho de 2012 pelo Núcleo de Estudos de Violência da USP, com dados de 2010, mostra que cerca da metade da população de 11 capitais do Brasil concordava, totalmente ou em parte, com o uso da tortura por parte da polícia, como método para obter provas de suspeitos. Esse dado contrasta com o de 1999, quando $71,2 \%$ da população discordava completamente do uso desse método. ${ }^{6}$

Numa resposta incompleta e impressionista a esses dados, deduzimos que qualquer decisão, legislativa ou judicial, para responsabilizar os agentes da repressão, não deverá resultar da expressiva mobilização da sociedade. Pode-

5 A pesquisa do IPEA foi realizada pelo Sistema de Indicadores de Percepção Social, SIPS Defesa Nacional, e está disponível no site da do Instituto: http://www.ipea.gov.br/. Acesso em: 20 ago. 2012.

6 Núcleo de Estudos da Violência da USP. Pesquisa nacional, por amostragem domiciliar, sobre atitudes, normas culturais e valores em relação à violação de direitos humanos e violência: um estudo em 11 capitais de estado. São Paulo: Núcleo de Estudos da Violência da Universidade de São Paulo, 2012. Diponível em: http://www. nevusp.org/. Acesso em: 20 ago. 2012. 
ria, sim, ser tomada pelas instituições pertinentes, especialmente o Judiciário, que poderia adotar posição contramajoritária. Dos três poderes no Brasil, ainda que precário e pouco incisivo, o Executivo foi o que mais ousou no sentido de esclarecer e reparar danos provocados pela ditadura. 0 Legislativo tem sido o grande ausente, e o Judiciário tem validado recorrentemente a interpretação de que a Lei de Anistia contempla crimes como a tortura e outras formas de desrespeito aos direitos humanos no que toca ao período ditatorial. É neste cenário de pouco interesse da sociedade, de inapetência dos Poderes, e de "cultura de conciliação", que se mantém intacta a Lei de Anistia aprovada em 1979, ainda em plena ditadura. Mais do que isso, ao contrário de outros países vizinhos, o Brasil não conseguiu levar a cabo outros recursos jurídicos que, contornando essa Lei, possibilitassem alguma forma de responsabilização criminal individual pelos crimes do período.

\section{A intocada Lei de Anistia de 1979 e as políticas de memória e reparação}

As estratégias do governo Ernesto Geisel (1974-1979) para negociar e conceber a anistia são peça chave para explicar a demorada retirada dos militares do poder. ${ }^{7}$ Foi uma transição que colocou como inegociável a imunidade militar, ou seja, a impunidade. Mesmo havendo forte oposição nos quartéis à retirada do poder, a coesão militar na saída colocava-se como imprescindível, e o discurso precisaria ser monolítico. A anistia que veio a ser desenhada visava, sobretudo, a impedir qualquer cisão nas Forças Armadas. Apesar das tensões internas à instituição, para efeitos do "público externo", os militares teriam que sair em bloco, protegidos judicialmente, e sem clivagens aparentes frente à sociedade. Fora do poder, nenhum grupo poderia reivindicar bravuras ou denunciar desmandos do regime. Para isso foi necessário uma auto-anistia, um compromisso corporativo em torno de um duradouro pacto de silêncio, envolto em um cinturão de segurança jurídica que, paradoxalmente, protegesse a impunidade.

A transição desenhada na segunda metade dos anos 1970 teve a preocupação de isolar os setores que mais resistiam à retirada do poder, e controlar o ritmo da mudança para impedir maior protagonismo das lideranças civis que demandavam a redemocratização. A meta era isolar setores militares adeptos do terrorismo, que não admitiam o retorno ao governo civil. Da mesma forma, impedir que a oposição civil impusesse, via mobilização social, a

7 Ver a esse respeito D, ARAUJO, Maria Celina e CASTRO, Celso. Ernesto Geisel. Rio de Janeiro: Editora FGV, 1997. 
sua agenda de mudanças. 0 ritmo da abertura e seu conteúdo seriam controlados pelos donos do poder, o que ficou conhecido como transição pelo alto ou transição pela transação. Para a maior parte dos analistas, os alter ego desta estratégia foram o presidente e general Ernesto Geisel e seu Chefe da Casa Civil, general Golbery do Couto e Silva, cujos passos e ações estão magistralmente registrados nos livros de Elio Gaspari. ${ }^{8}$

A Lei da Anistia em 1979 beneficiou vítimas e opressores, e funcionou como um escudo de proteção contra crimes praticados pelo governo. Desde então tem sido entendida como o encerramento de todas as pendências relativas ao período militar. Até mesmo os atentados a bomba no Riocentro, praticados em fins de abril de 1981, foram arquivados em nome dessa Lei.

Sintomaticamente, em sua primeira versão a Lei não mencionava a questão dos desaparecidos, um dos temas mais delicados para as Forças Armadas. Apenas em fins de 1995 foi criada a Comissão Especial sobre Mortos e Desaparecidos Políticos, vinculada ao Ministério da Justiça. A Comissão foi incumbida de pesquisar e elencar as pessoas mortas ou desaparecidas em decorrência de participação, ou de acusação de participação, em atividades políticas classificadas como ilegais pela ditadura, no período de 1961 a 1979, período coberto pela Lei de Anistia. Com essa Comissão, 16 anos depois da anistia, o governo brasileiro reconhecia que havia desaparecidos no país, mas estabelecia que a responsabilidade por esses fatos não recairia sobre a instituição militar, sobre o governo, ou sobre seus executores diretos, mas sim sobre o Estado. O Estado brasileiro reconhecia que havia cidadãos desaparecidos e mortos em decorrência de conflitos políticos, que cadáveres foram encobertos, e dispunha-se a regularizar a situação legal dessas pessoas e a amparar suas famílias. Tardiamente, começava-se o processo de reparação.

A Comissão foi composta por representantes de vários setores da sociedade e instituições, e por um representante das Forças Armadas. Pelos dados oficiais do Ministério da Justiça, o saldo da Comissão foi a análise de 475 casos. Destes, a Comissão indeferiu 118, chegando ao número oficial de 357 mortos e desaparecidos. Este reconhecimento resultou no pagamento de cerca de $\mathrm{R} \$ 40$ milhões de reais em indenizações. A maior parte dos desaparecidos era integrada por civis mortos em conseqüência da guerrilha rural na região amazônica, a guerrilha do Araguaia. Por isso mesmo o trabalho da Comissão pre-

8 Ver seus quatro livros: GASPARI, Elio. A ditadura envergonhada. São Paulo: Companhia das Letras, 2002; GASPARI, Elio. A ditadura escancarada. São Paulo: Companhia das Letras, 2002; GASPARI, Elio. A ditadura derrotada. São Paulo: Companhia das Letras, 2003; e, GASPARI, Elio. A ditadura encurralada. São Paulo: Companhia das Letras, 2004. 
via, numa segunda etapa, a localização das ossadas de 83 mortos nessa área, trabalho que se realiza lentamente e que ainda é um desafio.

A Comissão não apurou a responsabilidade individual pelas mortes e desaparecimentos. Atribuiu a responsabilidade ao Estado, mas forneceu dados abundantes sobre os responsáveis por esses crimes. Sem condições políticas de chegar à responsabilização individual, o Estado brasileiro dava a primeira prova de ser capaz de reparar injustiças. Simbolicamente, o próprio presidente da República, Fernando Henrique Cardoso, recebeu familiares de vários desses desaparecidos, em audiências oficiais, marcando publicamente o gesto de conciliação que ali se iniciava.

Dos trabalhos da Comissão resultou o livro Direito à Memória e à Verdade, lançado em agosto de 2007 pela Secretaria Especial de Direitos Humanos, sob a coordenação do ministro Paulo Vannuchi, e do qual extraímos os dados aqui informados. ${ }^{9}$ Este livro foi o primeiro documento oficial do governo federal, a declarar publicamente que a ditadura foi responsável por atos como decapitação, esquartejamento, estupro, tortura de modo geral, ocultação de cadáveres e execução.

O livro traz ainda as provas de que 64 casos de mortes e desaparecimentos que aconteceram no DOI-CODI de São Paulo, nos anos 1970, período em que o órgão estava sob o comando dos coronéis Carlos Alberto Brilhante Ustra e Audir Santos Maciel. Com base nessas informações, várias ações judiciais foram tentadas, todas sem sucesso até o momento.

Outro passo importante em termos de reparação foi a criação da Comissão de Anistia em 2001, encarregada de analisar os pedidos de indenização formulados por pessoas impedidas de exercer atividades econômicas e profissionais por motivação política no período compreendido entre setembro de 1946 e outubro de 1988, ano em que a nova Constituição brasileira entrou em vigor. Esta Comissão recebeu 57.637 requerimentos, a maioria já julgada, mas estima-se que o trabalho só será finalizado em 2016. ${ }^{10}$

No plano nacional e internacional intensificam-se as pressões para a liberação dos documentos militares sobre a ditadura e a tortura. A partir de 2005, dois projetos ganham dimensão nesse setor: Direito à Memória e à Verdade, da Secretaria Especial de Direitos Humanos da Presidência da República; e Memórias Reveladas, da Casa Civil da Presidência da República.

9 Brasil. Secretaria Especial dos Direitos Humanos. Comissão Especial sobre Mortos e Desaparecidos Politicos, Direito à verdade e à memória. Brasília: Secretaria Especial dos Direitos Humanos, 2007, disponível on line em http://portal.mj.gov.br/sedh/biblioteca/livro_direito_memoria_verdade/livro_direito_memoria_verdade_ sem_a_marca.pdf. Acesso em: Acesso em: 20 ago. 2012.

10 Revista Anistia Politica e Justiça de Transição, 2009, Apresentação. 
Este último, de 2008, prevê a disponibilização na internet, para consulta online, de todo material da repressão em poder do Arquivo Nacional. O projeto deu início também a uma campanha publicitária para coleta ao Arquivo de documentos guardados clandestinamente por militares, agentes da repressão e particulares. ${ }^{11}$

Todos os órgãos públicos começaram a enviar seus arquivos de censura interna e de informações ao Arquivo Nacional, à exceção das Forças Armadas. ${ }^{12}$ Oficialmente, afirmaram não possuir documentos a esse respeito. A instituição tomara para si a defesa daqueles que atuaram na repressão, e mandou destruir os documentos de suas sessões de informações. Nenhum colega de farda poderia ser atingindo por ações praticadas durante a ditadura, ainda que muitos já estivessem mortos. Tratava-se de zelar pelo nome da instituição e pela "honra" dos colegas fardados.

Ainda em fins de 2008, o governo enviou ao Congresso novo projeto de Lei de Acesso à Informação. A Lei que tratava de um dos pontos ainda mais delicados na democracia brasileira foi sancionada pela presidente da República em novembro de 2011. Na mesma data foi também sancionada a criação da Comissão da Verdade, que deveria examinar e esclarecer as violações de direitos humanos praticadas no período de 1946 até 1988. Segundo o decreto que a criou, tinha como objetivo "garantir o direito à memória e à verdade histórica e promover a reconciliação nacional”. A Comissão, altamente contestada pela corporação militar, teria mandato de dois anos, e passou a funcionar em maio de 2012. Não tinha poder para levar qualquer pessoa ou instituição a julgamento, nem poderia obrigar qualquer pessoa a depor contra sua vontade.

Importante notar que o debate e as iniciativas verificadas a partir dos anos 1990 em torno dos direitos humanos e da anistia, todos envolvendo e demandando provas documentais sobre o passado, reparação e até julgamentos, só foram possíveis em função de a democracia política ter passado a ser uma regra política estável no país. Foram possíveis também em decorrência das extensas reflexões políticas e jurídicas no plano internacional acerca da justiça de transição.

11 Ver site do Arquivo Nacional; http://www.arquivonacional.gov.br. Acesso em: 20 ago. 2012. Ver também D, ARAUJO, Maria Celina. Militares, democracia e desenvolvimento, Brasil e América do Sul. Rio de Janeiro: Editora FGV, 2009.

12 Durante a ditadura, os órgãos públicos tinham assessorias de informação que enviavam informações sobre seus funcionários aos serviços de inteligência militar e ao Serviço Nacional de Informações, SNI. 


\section{Notas sobre a justiça de transição}

Nos anos 1970 surgiu o termo justiça em cascata,,$^{13}$ quando a Grécia iniciava julgamentos políticos pós-transição e outros países como Portugal, Argentina, Bolívia e Guatemala seguiam ou ensaiavam seguir os mesmos passos. Estes tipos de julgamentos acabaram por se converter em recurso bastante comum nas décadas de 1990 e de 2000 em vários países que saíam de ditaduras e procuravam compor um sistema de direitos que enfrentasse a impunidade referente aos crimes do passado ditatorial. Foi aos poucos se consolidando na região e ganhou normas próprias dentro do Sistema Interamericano de Direitos Humanos.

Os debates sobre esta nova modalidade de justiça ganharam fôlego nas áreas do direito e nas ciências sociais em geral. No início dos anos 1990 surgiu o termo justiça de transição, para referir-se aos processos de transformação política e jurídica nas novas democracias na América Latina e na Europa do Leste. ${ }^{14} \mathrm{Em} 2004$ a justiça de transição foi definida pela ONU "como o conjunto de abordagens, mecanismos (judiciais e não judiciais) e estratégias para enfrentar o legado de violência em massa do passado, para atribuir responsabilidades, para exigir a efetividade do direito à memória e à verdade, para fortalecer as instituições com valores democráticos e garantir a não repetição das atrocidades". ${ }^{15}$

Justiça de transição refere-se, portanto, a um conceito de origem recente e sofisticado, que remete a áreas de direito altamente especializadas. Para efeitos deste trabalho, vamos arrolar uma série de aspectos que parecem os mais importantes quando se discute a situação do Brasil. Resumidamente esses temas são:

- investigar, processar, julgar e punir os violadores de direitos humanos;

- revelar a verdade para as vítimas, seus familiares e toda a sociedade;

- oferecer reparação adequada às vítimas do arbítrio;

- afastar os criminosos do exercício de funções nos órgãos públicos;

- reformar as instituições para a democracia;

13 Uma das principais formuladoras desse conceito é Sikkink; ver SIKKINK, Kathryn e LUTZ, Ellen. The justice cascade: the evolution and impact of foreign human rights trials in Latin America. Chicago: Journal of International Law, v.2, n.1, p.1-33, Spring 2001; e SIKKINK, Kathryn. A era da responsabilização: a ascensão da responsabilização penal individual. In: COMISSÃO DE ANISTIA. A anistia na era da responsabilização, p. 34-74.

14 TEITEL, Ruti G. Transitional justice. New York: Oxford University Press, 2000, é considerada a criadora do termo.

15 UN Security Council. The rule of law and transitional justice in conflict and post-conflict societies. Report Secretary-General, S/2004/616. Ver: SOARES, Inês Virginia Prado. Justiça de Transição. In: VV. AA. Dicionário de Direito Humanos, disponível em http://www.esmpu.gov.br/dicionario/tiki-index.php?page=Como+escrever $+\mathrm{n}$ o+Dicion\%C3\%A1rio. Acesso em: 20 ago. 2012. 
- efetivar o direito à memória;

- garantir o igual tratamento de todos frente à Lei e à Justiça;

- promover a conscientização sobre direitos humanos e justiça;

- viabilizar a reconciliação política.

Em suma, justiça de transição nos leva a um pequeno, mas expressivo conjunto de palavras: verdade, memória, reparação, informação, investigação, julgamentos, justiça, responsabilização estatal e individual.

Isso nos distancia da percepção que orientou a Lei de Anistia, ou seja, a da conciliação nacional com base na ideia de que o legado criminoso da ditadura nunca poderia ser questionado. É comum ouvir-se da parte dos militares a expressão "virar a página", no sentido de que a Lei de Anistia impediria "revanchismos" e com isso se manteria a reconciliação concebida e pensada pelas Forças Armadas: o esquecimento deveria ser a regra, até mesmo para perdoar o que não se conhecia. ${ }^{16}$

Apesar da posição inflexível das Forças Armadas a favor do esquecimento, a partir dos anos 1990, como vimos, foi ganhando corpo no país o debate sobre memória e reparação, quer na academia, quer em algumas áreas do governo. Isso se deveu em grande parte à experiência internacional e aos novos paradigmas sobre justiça e transição.

Para Javier Ciurlizza, em função desses debates, as transições políticas não podiam mais ser levadas a cabo apenas a partir de um pacto político. Seria necessária a via do enfrentamento jurídico, político e ético. ${ }^{17} \mathrm{Em}$ particular, deveria ser dada maior relevância aos direitos das vítimas para conhecerem o passado e obterem reparações, além da punição criminal para os responsáveis pelos crimes de que foram vítimas.

Esse intenso debate levou a mudanças na atuação da Secretaria Especial de Direitos Humanos e do Ministério da Justiça, que colocaram as preocupações da justiça de transição no centro de sua agenda política. Partiu-se do suposto levantado por Teitel, ${ }^{18}$ de que o Estado de Direito assume características excepcionais em "momentos fundacionais" como os de transição política. Nestas ocasiões o Estado, além de suas funções habituais, tem por obrigação promover a construção da mudança política.

Segundo Santos, fazendo a retrospectiva da justiça de transição desde o final da Segunda Guerra Mundial, Teitel teria identificado três fases: a pri-

\footnotetext{
16 SILVA FILHO, José Carlos Moreira da. Memória e reconciliação nacional: o impasse da anistia na inacabada transição democrática brasileira. In: COMISSÃO DE ANISTIA. A anistia na era da responsabilização, p. 278307.

17 CIURLIZZA, Javier. Entrevista: Para um panorama global sobre a justiça de transição. Revista Anistia Política e Justiça de Transição, Brasília: Ministério da Justiça, n.1, p. 23-29, jan./jun 2009.

18 TEITEL, Ruti G. Transitional justice.
} 
meira, sui generis, foi marcada pelos tribunais de Nuremberg. A segunda remetia às transições para a democracia na América Latina e à queda do bloco comunista a partir dos anos 1980. A terceira teria se caracterizado pela globalização do paradigma de justiça de transição, embora a história de cada país pudesse moldar sua aplicabilidade e limites. ${ }^{19}$

Da mesma forma e percorrendo mais ou menos os mesmos marcos factuais, Brito identifica três “ondas" de justiça transicional na Europa: o período imediato do pós-Segunda Guerra, a transição política no sul da Europa, ou seja, Grécia, Portugal e Espanha, e as transições dos anos 1990 na Europa Central e do Leste. ${ }^{20}$

Há certo consenso também no fato de que na América Latina, as políticas transicionais ocorridas a partir de meados da década de 1980, deram origem às "comissões da verdade", a mais famosa com lugar na Argentina. A América Latina possuiria reconhecidamente uma notável história de julgamentos por violações dos direitos humanos, embora não seja a região do mundo que mais praticou justiça em termos de julgamentos. De toda forma, alguns processos se tornaram mundialmente famosos como os das juntas militares da Argentina e o de Augusto Pinochet no Chile. Da mesma maneira, altos dirigentes e presidentes da Bolívia, Uruguai e Peru, por exemplo, enfrentaram os tribunais, foram julgados, processados ou extraditados. ${ }^{21}$

Olsen, Payne e Reiter constataram que a América Latina alcançou a vanguarda na instalação de comissões de verdade e na promulgação de anistias, mas não nos julgamentos. Mas alertam para uma tendência paradoxal: as anistias, em alguns casos, foram acompanhadas por julgamentos de violações dos direitos humanos. Ou seja, as anistias não representaram simplesmente impunidade. Continuam o raciocínio, afirmando que suas pesquisas sugerem que a combinação de anistias com julgamentos e comissões da verdade pode fortalecer a democracia, e reduzir violações dos

19 SANTOS, Cecília MacDowell. Questões de justiça de transição: a mobilização dos direitos humanos e a memória da ditadura no Brasil. In: COMISSÃO DE ANISTIA. Repressão e Memória Política no Contexto IberoBrasileiro: estudos sobre Brasil, Guatemala, Moçambique, Peru e Portugal. Brasília/Coimbra: Ministério da Justiça, Comissão de Anistia, Universidade de Coimbra, Centro de Estudos Sociais, 2010, p. 124-151.

20 BRITO, Alexandra Barahona de. Justiça transicional e a política da memória: uma visão global sociedades pósconflito. Revista Anistia Politica e Justiça de Transição. Brasília: Ministério da Justiça, n. 1, p. 56-83, jan./jun. 2009.

21 A esse respeito ver OLSEN, Tricia D., PAYNE, Leigh A. e REITER, Andrew G.. Equilibrando julgamentos e anistias na América Latina: perspectivas comparativa e teórica. Revista Anistia Política e Justiça de Transição. Brasília: Ministério da Justiça, n.2, p. 152-175, jul./dez.2009; e, OLSEN, Tricia D.; PAYNE, Leigh A. e REITER, Andrew G. As implicações políticas dos processos de anistia. In: COMISSÃO DA ANISTIA. A anistia na era da responsabilização, p. 542-571. 
direitos humanos. Essa combinação foi chamada de "tendência para mecanismos de equilíbrio". 22

A América Latina não seria um exemplo de justiça em cascata, mas sua experiência possibilitou que as transições na América Latina apresentassem, em geral, melhorias nas políticas e práticas dos direitos humanos e na democracia. 0 dado importante deste artigo é mostrar que anistia e julgamentos podem ser combinados, e que necessariamente a anistia não inviabiliza mecanismos de justiça de transição. ${ }^{23}$

A posição dos autores, confirmada por pesquisas empíricas e pela Base de Dados da Justiça de Transição, é a de que as anistias trazem de fato melhorias para a democracia e os direitos humanos quando combinadas com julgamentos ou com julgamentos e comissões de verdade, ou seja, quando houver um "equilíbrio de justiça". Com base nisso afirmam que a "era da responsabilização" não estaria eliminando o uso ou a utilidade das anistias.

Em outro artigo, ${ }^{24}$ os autores enfatizam ser falsa a dicotomia entre anistia e impunidade. Sustentam que as anistias desempenham papel construtivo na promoção de objetivos políticos democráticos, enquanto estiverem acompanhadas da apuração da verdade que promova a conscientização da sociedade sobre os crimes do passado. Esta é uma visão que valoriza o papel que a anistia pode desempenhar no reforço da democracia e na proteção dos direitos humanos. Neste sentido, as comissões de verdade, ao documentar atrocidades, esclareceriam responsabilidades e poderiam levar à condenação das violações dos direitos humanos, sem instaurar processos judiciais que pudessem mobilizar as forças antidemocráticas.

Lembre-se, a esse respeito, que a maioria dos países latino-americanos que praticou julgamentos dos crimes da ditadura o fez contornando, e não derrubando, suas leis de anistia. Este é um modelo que o Brasil tem tentado seguir, até hoje sem sucesso, visto que o Supremo Tribunal Federal, a mais alta Corte do país, tem decidido pela impossibilidade constitucional de levar torturadores ao banco dos réus.

Isso nos remete ao tema conceitual da responsabilização em suas três vertentes: a vertente da "imunidade" entendida de fato e de direito como impunidade, modelo predominante até a Segunda Guerra Mundial; a responsabilização penal estatal que se praticou depois da Segunda Guerra Mundial;

22 OLSEN, Tricia D., PAYNE, Leigh A. e REITER, Andrew G.. Equilibrando julgamentos e anistias na América Latina; e OLSEN, Tricia D.; PAYNE, Leigh A. e REITER, Andrew G. As implicações políticas dos processos de anistia.

23 Sobre as anistias na América Latina ver, por exemplo, MALLINDER, Louise. Perspectivas transnacionais sobre a anistia. In: COMISSÃO DE ANISTIA. A anistia na era da responsabilização, p. 470-505.

24 OLSEN, Tricia D.; PAYNE, Leigh A. e REITER, Andrew G. As implicações políticas dos processos de anistia, p. $542-571$. 
e a responsabilização penal individual, preconizada a partir das décadas de 1980 e 1990, para crimes como tortura, execução sumária, genocídio, crimes de guerra e crimes contra a humanidade. ${ }^{25} \mathrm{Um}$ marco deste tipo de responsabilização foi a prisão de Pinochet em Londres em 1998, cujos impactos sobre as possibilidades punitivas das ditaduras geraram o que alguns chamaram "efeito Pinochet".

A expressão "era da responsabilização", gestada a partir de então, influenciou profundamente as discussões no país e embasou argumentos dos que propõem o fim da Lei de Anistia ou uma nova interpretação legal que permita julgamentos daqueles que violaram os direitos humanos durante a ditadura.

Autores e analistas como Abrão e Torelly concluem, com razão, que no Brasil o eixo estruturante da agenda da transição política tem sido até agora o da reparação, e que a maior parte das medidas nessa direção, ainda que tardias, partiram do Poder Executivo. ${ }^{26}$ Para os autores, se o eixo da reparação nos fez avançar até agora na agenda da democratização, dois grandes desafios ainda precisam ser enfrentados: verdade e justiça.

Para os autores, esse delay do Brasil pode ser examinado por vários ângulos. 0 primeiro tem a ver com a lenta transição brasileira controlada pelo militares, que acabaram impondo sua tese de "anistia bilateral". 0 segundo remete à ação do Poder Judiciário que "legalizou" a ditadura, aceitando sempre a tese de que os crimes do regime eram conexos aos crimes da oposição e da resistência armada. 0 terceiro aspecto diz respeito à ação dos movimentos da sociedade civil, que passaram a privilegiar demandas antes reprimidas, tais como reforma agrária, direitos de gênero, de etnia, direitos das crianças e dos adolescentes, meio ambiente etc. A ampla agenda teria reservado espaço limitado ao tema da justiça de transição.

\section{Militares como veto players}

Pouca atenção tem sido dada nos debates sobre justiça de transição no Brasil ao papel das Forças Armadas, na intocabilidade da Lei de Anistia desde 1979. Este é o ponto que queremos marcar neste trabalho, demonstrando e explicando como esse padrão pode ser mantido até agora.

Desde a Lei de Anistia de 1979, várias medidas foram tomadas visando à reconciliação e à reparação. Todavia, nenhuma iniciativa foi bem sucedida quando se tratou de apurar responsabilidades. O Brasil optou por medidas

25 SIKKINK, Kathryn e LUTZ, Ellen. The justice cascade.

26 ABRÃO, Paulo e TORELLY, Marcelo D. As dimensões da Justiça de Transição no Brasil, a eficácia da Lei de Anistia e as alternativas para a verdade e a justiça. In: COMISSÃO DE ANISTIA. A anistia na era da responsabilização, p. 212-248. 
gradativas que refletiram sua precariedade na cultura de direitos humanos, e garantiram até meados de 2012, a impunidade. Isso destoa, como vimos, de outras experiências de países vizinhos, que mesmo tendo uma lei de anistia em vigor, usaram as leis ordinárias para punir torturadores, como no caso do Uruguai e do Chile. ${ }^{27}$

Até o momento, está em andamento no Brasil um precário processo de controle civil e democrático sobre as Forças Armadas, com os limites impostos nas negociações para o fim do regime e na Lei da Anistia. Os militares ainda recebem tratamento diferenciado em vários aspectos, como uma justiça corporativa e um sistema próprio e generoso de aposentadorias e de assistência social se comparado ao resto do país. Além disso, mantêm controle sobre o Ministério da Defesa e sobre a definição da educação e da estratégia de defesa. Com apoio civil e do Judiciário, têm mantido o poder de veto quando se trata de discutir o desrespeito aos direitos humanos durante a ditadura.

O poder das Forças Armadas no tema da anistia vai além, portanto, das questões de transição. Tem a ver com o tipo de relações civil-militares gestadas no país desde a fundação da República, quando as Forças Armadas se transformam em ator político relevante. Desde então, com maior ou menor peso, os militares vêm tentando manter um padrão de autonomia quando se trata de definir seus interesses corporativos. Isso tem a ver com orçamentos, carreira, educação militar, definição de ameaças e estratégias e, certamente, com sua atuação durante a ditadura. Mesmo com a redemocratização, nenhum governo civil ousou encarar com determinação o tema da subordinação dos militares ao poder civil e democrático.

Pode-se dizer que durante o governo José Sarney houve uma tutela militar, que foi diminuindo nos governos seguintes, sem que a autonomia fosse alterada. 0 único governo que ousou enfrentar os militares redefinindo instituições foi o de Collor de Mello marcado, contudo, pela instabilidade política. Nos governos seguintes, consolidou-se um modus operandi entre o presidente e Forças Armadas, no sentido de que não seriam "incomodadas" com temas “delicados" e, logo, não incomodariam o presidente. Como o risco de golpes militares deixara de existir, abriu-se mão de uma política de efetivo controle

27 No Cone Sul ocorreram as seguintes ditaduras: Argentina (1976-1982), Brasil (1964-1985), Chile (1973-1990), Paraguai (1954-1989) e Uruguai (1973-1985). Sobre a justiça de transição nesses países e na América Latina, ver, por exemplo, ARRIAZA, Naomi Roht. Impunidade na América Latina: tribunais nacionais e desafios ainda existentes. In: COMISSÃO DE ANISTIA. A anistia na era da responsabilização, p. 140-160; AGUILAR, Paloma. A Lei Espanhola de Anistia de 1977 em perspectiva comparada: de uma lei pela democracia a uma lei pela impunidade. In: COMISSÃO DE ANISTIA. A anistia na era da responsabilização, p. 394-426.; e, SKAAR, Elin. Impunidade versus responsabilidade no Uruguai: o papel da Ley de Caducidad. In: COMISSÃO DE ANISTIA. A anistia na era da responsabilização, p. 428-469. Sobre essas ditaduras, ver também CASTRO, Celso e D'ARAUJO, Maria Celina. (orgs.). Democracia e Forças Armadas no Cone Sul. Rio de Janeiro: FGV Editora, 2000. 
civil. Foi apenas no governo Lula da Silva que esse pacto pareceu ter sido alterado por parte de alguns setores do Poder Executivo. Não por acaso, foi também nesse governo que mais concessões foram feitas à autonomia militar.

Vamos analisar alguns episódios exemplares em que, ao tratar do tema da tortura, o governo teve que se retrair. ${ }^{28}$ Paradoxalmente, as concessões aos militares aumentaram na medida em que as pressões por verdade e responsabilização cresceram. Elas foram mais marcantes a partir do governo Lula da Silva. Nesses momentos, os militares reagiram organizadamente, e o governo recuou publicamente. Ferindo a disciplina, os militares foram bem sucedidos como veto players.

\section{a) Ato I - Queda do ministro da Defesa José Viegas em 2004}

Em meados de outubro de 2004, a imprensa divulgou foto de um preso enforcado numa cela, identificado como sendo o jornalista Wladimir Herzog. A foto realimentou a temática sobre os crimes e os documentos da ditadura. A reação militar foi imediata. Em 17 de outubro de 2004, o Serviço de Comunicação Social do Exército, sem consultar o ministro da Defesa, justificou a ação das Forças Armadas no combate ao comunismo, lançando nota em que o comandante do Exército defendia o golpe de 1964 e a ação repressiva das Forças Armadas durante a ditadura. A nota afirmava:

Desde meados da década de 60 até início dos anos 70 ocorreu no Brasil um movimento subversivo, que atuando a mando de conhecidos centros de irradiação do movimento comunista internacional, pretendia derrubar, pela força, o governo brasileiro legalmente constituído.

$\mathrm{Na}$ época, o Exército Brasileiro, obedecendo ao clamor popular, integrou, juntamente com as demais Forças Armadas, a Polícia Federal e as polícias militares e civis estaduais, uma força de pacificação, que logrou retomar o Brasil a normalidade. As medidas tomadas pelas forças legais foram uma legítima resposta a violência dos que recusaram o diálogo, optaram pelo radicalismo e pela ilegalidade e tomaram a iniciativa de pegar em armas e desencadear ações criminosas.

(...) Quanto às mortes que teriam ocorrido durante as operações, o Ministério da Defesa tem, insistentemente, enfatizado que não há documentos históricos que as comprovem, tendo em vista que os registros operacionais e da atividade de inteligência da época foram destruídos em virtude de determinação legal.

(...) Coerente com seu posicionamento, e cioso de seus deveres constitucionais, o Exército brasileiro, bem como as Forças coirmãs, vão demonstrando

28 Vamos tratar aqui apenas de casos que envolvam o tema de anistia. Em outros campos como o da demarcação de terras indígenas e do controle da aviação civil, por exemplo, houve confrontos e o governo lidou silenciosamente com atos de indisciplina militar. 
total identidade com o espírito da Lei da Anistia, cujo objetivo foi proporcionar ao nosso país um ambiente pacífico e ordeiro, propício para a consolidação da democracia e ao nosso desenvolvimento, livre de ressentimentos e capaz de inibir a reabertura de feridas que precisam ser, definitivamente, cicatrizadas. Por esse motivo considera os fatos como parte da História do Brasil. Mesmo sem qualquer mudança de posicionamento e de convicções em relação ao que aconteceu naquele período histórico, considera ação pequena reavivar revanchismos ou estimular discussões estéreis sobre conjunturas passadas, que a nada conduzem. ${ }^{29}$

A declaração produziu mal-estar no governo. Depois de várias conversações entre o presidente da República e as autoridades militares, decidiu-se encerrar ao assunto com uma nota de retratação do comandante do Exército, Francisco Roberto de Albuquerque, em que lamentava a morte do jornalista Herzog, e afirmava o apreço dos militares pela democracia. Mais uma vez destacava que as Forças Armadas não queriam reavivar fatos do passado:

O Exército Brasileiro é uma instituição que prima pela consolidação do poder da democracia brasileira. 0 Exército lamenta a morte do jornalista Vladimir Herzog. Cumpre relembrar que, à época, este fato foi um dos motivadores do afastamento do comandante militar da área, por determinação do presidente Geisel. Portanto, para o bem da democracia e comprometido com as leis do nosso país, o Exército não quer ficar reavivando fatos de um passado trágico que ocorreram no Brasil. Entendo que a forma pela qual esse assunto foi abordado não foi apropriada, e que somente a ausência de uma discussão interna mais profunda sobre o tema pode fazer com que uma nota do Centro de Comunicação Social do Exército não condizente com o momento histórico atual fosse publicada. Reitero ao senhor presidente da República e ao senhor ministro da Defesa a convicção de que o Exército não foge aos seus compromissos de fortalecimento da democracia brasileira. ${ }^{30}$

Os fatos e as fotos fortaleceram a ideia de que os arquivos da ditadura precisavam ser encontrados e abertos. A Câmara dos Deputados solicitou empenho do ministro da Defesa, José Viegas, nesse sentido. 0 próprio ministro admitia que nem todos os documentos haviam sido destruídos. ${ }^{31}$ Os militares, por sua vez, dão uma série de declarações negando a existência desses papeis. O chefe do Centro de Comunicação da Aeronáutica, brigadeiro Antônio Telles Ribeiro, afirmou que os arquivos da Aeronáutica da época da ditadura foram destruídos em um incêndio do aeroporto Santos Dumont em 1998.

29 A nota foi publicada na íntegra pelos principais jornais do país.

30 Esta nota é de 19 de outubro de 2004, e foi publicada em todos os grandes jornais do país.

31 O Globo, 21 de outubro de 2004. 
A polêmica em torno da abertura desses arquivos foi a gota d'água para a demissão do ministro da Defesa, José Viegas, substituído na pasta pelo vice presidente da República José Alencar. Na carta de demissão de 22 de outubro de 2004, amplamente divulgada na ocasião, deixava claras as divergências com o comando do Exército:

Após uma reflexão prolongada a respeito das ocorrências dessa semana, julgo necessária uma atribuição mais efetiva de responsabilidades com relação à nota emitida pelo Exército no último domingo. Embora a nota não tenha sido objeto de consulta ao Ministério da Defesa, e até mesmo por isso, uma vez que o Exército Brasileiro não deve emitir qualquer nota com conteúdo político sem consultar o Ministério, assumo a responsabilidade que me cabe, como dirigente superior das Forças Armadas, e apresento a minha renúncia ao cargo de Ministro da Defesa.

(...) Foi, portanto, com surpresa e consternação, que vi publicada no domingo, dia 17, a nota escrita em nome do Exército Brasileiro que, usando linguagem totalmente inadequada, buscava justificar lamentáveis episódios do passado e dava a impressão de que o Exército, ou, mais apropriadamente, os que redigiram a nota e autorizaram a sua publicação, vivem ainda o clima dos anos setenta, que todos queremos superar.

(...) É incrível que a nota original se refira, no século 21, a 'movimento subversivo' e a 'Movimento Comunista Internacional'. É inaceitável que a nota use incorretamente o nome do Ministério da Defesa em uma tentativa de negar ou justificar mortes como a de Vladimir Herzog. É também inaceitável, a meu ver, que se apresente o Exército como uma instituição que não precise efetuar 'qualquer mudança de posicionamento e de convicções em relação ao que aconteceu naquele período histórico’.

Um comandante indisciplinado fora poupado, e o ministro José Viegas desautorizado em seu papel de ministro da Defesa. Para a demissão de Viegas contribuíra também, a lentidão dos trabalhos da Comissão Interministerial criada com a finalidade de localizar os restos mortais de participantes da Guerrilha do Araguaia. ${ }^{32}$ Esta Comissão foi composta pelos ministros da Justiça, da Casa Civil, pelo Advogado-Geral da União, pelo Secretário Especial dos Direitos Humanos, e pelos comandantes da Marinha, do Exército e da Aeronáutica. O ministro cobrava das autoridades militares mais empenho em seus trabalhos, e as divergências acabaram por esvaziá-la. De fato, até o momento, apenas dois corpos de guerrilheiros foram identificados, embora outros corpos tenham sido encontrados na região. ${ }^{33}$

32 Decreto $^{\circ} 4.850$, de 20 de outubro de 2003.

33 Sobre a guerrilha do Araguaia, a obra mais completa é NOSSA, Leonencio. Mata! - o major Curió e as guerrilhas no Araguaia. São Paulo: Companhia das Letras, 2012. 
A substituição de José Viegas no Ministério da Defesa pelo vice-presidente da República, José Alencar, foi uma manobra política do presidente para prestigiar as Forças Armadas, preservar sua autonomia e mantê-las fora do debate governamental.

\section{b) Ato II - Tasso Genro e a revisão da Lei de Anistia}

No ano de 2008 o ministro da Justiça, Tarso Genro, filiado ao PT, lançou na Associação Brasileira de Imprensa ( $A B I)$, no Rio de Janeiro, a Caravana da Anistia, que liderou e acompanhou até deixar o Ministério no início de 2010. A iniciativa tinha como objetivo, fazer com que a Comissão de Anistia corresse todo o país, até o ano de 2010, para acelerar o julgamento dos processos de anistia em cada estado da federação, e motivar a sociedade a considerar a seriedade do tema dos direitos humanos.

Num de seus pronunciamentos Tasso Genro declarou:

A anistia não é um esquecimento, nem contribuição financeira, porque o Estado nunca vai pagar todos os tipos de prejuízo que as pessoas que se opuseram ao regime militar tiveram. É um processo integrante da constituição do Estado democrático de direito e o momento pelo qual o país está passando é importante para a consolidação da democracia e da República. ${ }^{34}$

E acrescentava: "Dizem que a anistia foi feita para todos, inclusive para os torturadores. Eu respondo que os torturadores têm que ser julgados, têm que receber uma pena. Eles se escondem hoje em uma postura arrogante que não aceita a controvérsia política". ${ }^{35}$ Sua tese de era a de que a tortura não constituía crime político, e sim crime contra a humanidade. Em sendo assim, se o Poder Judiciário fizesse essa interpretação, não seria necessário fazer mudanças na Lei da Anistia para punir os torturadores. Na mesma época, o ministro defendeu a abertura dos arquivos secretos do período da ditadura.

As tensões com os militares eram explícitas, e o ministro defendia a visão de que o julgamento dos torturadores não representava ofensa às Forças Armadas. Segundo ele, a própria ditadura não defendeu a tortura:

Tratar da questão da tortura não é revanchismo político. Em nenhuma legislação a tortura é considerada crime político, mas sim crime contra a vida. 0 regime autoritário brasileiro permitia prisões arbitrárias e até inconstitucionais, mas a tortura nunca foi permitida pelas próprias leis da ditadura. Logo, a violência contra uma pessoa presa, a tortura, é considerada crime comum, seja cometido por agentes do Estado, seja por pessoas contrárias ao regime. ${ }^{36}$

34 Jornal da ABI, n 329 , maio 2008.

35 Folha de São Paulo Online, 15 de maio de 2008.

36 O Globo, 8 de maio de 2008. 
Em meio a isso foi realizada Audiência Pública no Ministério da Justiça para ouvir ministros, advogados, e representantes de entidades da sociedade civil sobre o tema da anistia. O evento intitulado "Limites e Possibilidades para a Responsabilização Jurídica dos Agentes Violadores de Direitos Humanos durante o Estado de Exceção no Brasil" não contou com a presença de representantes da Forças Armadas. Propunha-se a examinar a possível punição dos torturadores nos campos civil e penal. Para o presidente da Comissão de Anistia, Paulo Abrão, a Constituição de 1988 descreveu a tortura como crime imprescritível, e não poderia haver conciliação nessa matéria. ${ }^{37}$

Nessa Audiência, pela primeira vez o Estado brasileiro discutiu a possibilidade de processar judicialmente os agentes públicos que cometeram crimes contra os direitos humanos durante a ditadura. Em seguida, a Ordem dos Advogados do Brasil propôs ao Supremo Tribunal Federal, uma Arguição de Descumprimento de Preceito Fundamental, questionando a legalidade da interpretação da Lei que concedia anistia a crimes de tortura. ${ }^{38} \mathrm{~A}$ Suprema Corte brasileira, por sete votos a dois, decidiu, em 29 de abril de 2010, declarar válida a Lei de Anistia para todos os crimes cometidos por agentes de Estado no Brasil durante a ditadura.

Em reação à realização desta Audiência Pública, considerada uma afronta por vários setores militares, os clubes Militar, Naval e Aeronáutico, decidiram realizar no Rio de Janeiro, um seminário intitulado "Lei da Anistia: alcances e conseqüências". ${ }^{39}$ Nos pronunciamentos dos palestrantes foi feita a defesa do golpe de 1964, justificada a "guerra suja" contra a oposição durante a ditadura, e relembrado que a anistia foi feita em nome da pacificação, o que permitiu que muitos "ex-terroristas" tivessem chegado ao poder. ${ }^{40} \mathrm{~A}$ imprensa noticiou frases agressivas pronunciadas no evento contra o então ministro da Justiça, evidenciando as tensões do momento. Entre elas, a do deputado Jair Bolsonaro, de que "o erro foi torturar e não matar". ${ }^{41}$

Diante deste enfrentamento, as autoridades da República passam a se movimentar para minimizar os efeitos do descontentamento entre os fardados. Examina-se também a possibilidade de punir os oficiais da ativa que participaram do seminário, ou que se manifestaram publicamente sobre o tema, desrespeitando os regulamentos disciplinares.

Com a intervenção do ministro da Defesa, Nelson Jobim, o assunto começou a ser encerrado de forma a não descontentar, e a não punir os militares.

\footnotetext{
37 Folha de São Paulo Online, 31de julho de 2008.

38 ADPF n. ${ }^{\circ} 153 / 2008$.

39 O Globo, 2 de agosto de 2008.

40 A íntegra desses pronunciamentos está em http://www.brasildefato.com.br. Acesso em 01 mar. 2009

41 Folha de São Paulo Online, 9 de agosto de 2009.
} 
Em solenidade no Planalto, durante apresentação dos oficiais-generais promovidos, o ministro Jobim descartou qualquer possibilidade de o comandante militar do Leste, general Luiz Cesário da Silveira, e de o chefe de departamento de Ensino e Pesquisa do Exército, general Paulo César Castro, serem punidos por terem participado de manifestações públicas a esse respeito. ${ }^{42}$ Ou seja, em nome da pacificação nas relações do governo com as Forças Armadas o ministro, em nome do presidente, endossou a indisciplina ou a ignorou.

No dia seguinte, durante reunião da Coordenação Política, realizada no Palácio do Planalto, o presidente Lula orientou os ministros Tarso Genro e Paulo Vannuchi a não mais debaterem em público o tema da punição dos militares que praticaram a tortura durante a ditadura, e a não declararem publicamente seu posicionamento acerca da revisão da Lei da Anistia. Mais uma vez, as Forças Armadas saíam vencedoras: o presidente da República vetou o debate.

\section{c) Ato III - A Comissão Nacional da Verdade}

Em dezembro de 2009, novo atrito surgiu entre o governo e as Forças Armadas. 0 governo assinou o decreto que criava o Terceiro Plano Nacional de Direitos Humanos, em que constava a criação de uma Comissão Nacional da Verdade, responsável por "promover esclarecimento público das violações de Direitos Humanos por agentes do Estado na repressão aos opositores". ${ }^{43}$ Os comandantes militares ameaçaram renunciar a seus cargos caso a Comissão fosse criada, e o ministro da Defesa solidariamente os acompanhou nesta posição. O presidente da República, mais uma vez, acatou a demanda dos militares, e o assunto foi postergado. 0 ano seguinte, o de 2010, foi um ano eleitoral e o assunto saiu da agenda.

Apenas em novembro de 2011 que a Comissão da Verdade foi criada, iniciando-se uma nova rodada de afrontas à Presidência da República. O conflito se intensificou em fevereiro de 2012, quando duas ministras de Estado declararam-se publicamente favoráveis à revisão da Lei de Anistia. Por meio do Clube Militar, as Forças Armadas lançaram nota criticando a presidente por não ter advertido suas auxiliares, o que denotaria conivência com as posições das ministras. Isso seria uma indicação de que o governo não estaria disposto a respeitar o ordenamento jurídico do país, tendo em vista que a Lei de Anistia fora reiteradamente declarada constitucional pelo STF. Na nota afirmava-se:

Os Clubes Militares expressam a preocupação com as manifestações de auxiliares da Presidente sem que ela, como a mandatária maior da nação, venha a público expressar desacordo com a posição assumida por eles e pelo partido

42 O Estado de S. Paulo, 12 de agosto de 2008.

43 O Primeiro Plano Nacional de Direitos Humanos foi editado em 1996, e o Segundo em 2002. 
ao qual é filiada e aguardam com expectativa positiva a postura de Presidente de todos os brasileiros e não de minorias sectárias ou de partidos políticos.

Resumindo, representantes da reserva e da ativa das três Forças lançaram nota criticando a presidente Dilma Rousseff por ser complacente com seu partido e com pronunciamentos de auxiliares diretos favoráveis à punição de torturadores; a presidente pediu ao ministro da Defesa, Celso Amorim, para censurar a nota; o Clube retirou a nota de sua página na internet, mas lançou outra afirmando que o ministro não tinha autoridade ou legitimidade para coordenar as Forças Armadas, e que a presidente era "despreparada"; a presidente pediu punições e ordenou ao ministro da Defesa que administrasse silenciosamente a desrespeitosa polêmica; o ministro ordenou aos comandantes que administrassem internamente a aplicação da disciplina militar.

$O$ assunto saiu dos jornais até o mês de abril, quando o Clube Militar celebrou o $48^{\circ}$ aniversário do golpe de 1964, numa sinalização clara de descontentamento para com as políticas do governo relativas à memória e à "verdade histórica".

Segundo a imprensa, nessa ocasião, cerca de 300 manifestantes de partidos de esquerda e de movimentos sociais cercaram a sede do Clube com palavras de ordem contra a ditadura, a tortura e os torturadores. Ovos e tinta vermelha atingiram vários dos participantes, o que foi entendido pelos militares como uma manifestação de intolerância política. A partir daí, ações desse teor, denominadas de "escrachos", passaram a ocorrer esporadicamente em ambientes militares e em prédios e casas onde moravam pessoas identificadas como torturadores.

As críticas dos militares ao governo Dilma Rousseff, incluindo possibilidades de "desordem" ou de "levante em nome da honra", ganharam volume nas redes sociais. De toda forma, os militares foram vencedores: a Comissão da Verdade não terá poder para levar qualquer pessoa a julgamento, e ninguém será obrigado a depor se for chamado. Ou seja, nenhum militar precisará passar pelo constrangimento de ter que explicar o que fez como agente da repressão. Muito menos precisará, em função dos resultados da Comissão, responder em juízo por seus atos.

A Comissão da Verdade foi criada 35 anos depois da Lei de Anistia. Ou seja, independente da questão semântica e ousada de seu nome, é uma Comissão tardia que visa a recuperar informações e registros sobre ações violentas dos agentes do Estado. A maior parte desses agentes (executores diretos ou mandantes) já está em idade avançada ou já morreu. Além de tardia, representa mais uma etapa no processo de justiça de transição, mas não se propõe a produzir justiça e julgamentos. É uma Comissão com funções tímidas, 
se pensarmos as ações que outros países já implementaram. De toda forma, a reação dos militares é surpreendente. Defendem a instituição com os mesmos argumentos da guerra fria, o que indica que os processos de socialização interna, de educação, e instrução militares, ainda não acompanham os passos de uma sociedade democrática, que não pode constitucionalmente ter protagonismo militar. De igual modo dão evidências de estar longe dos debates internacionais sobre formato e papel das Forças Armadas pós-guerra fria. ${ }^{44}$

Apesar das posições que o governo tem adotado no sentido de atender a demandas de familiares que querem levar torturadores a julgamentos, os militares têm sido os vencedores. A Justiça e a chantagem corporativa ficaram do lado da posição que entende anistia como amnésia e como perdão. Grande parte da sociedade brasileira também endossa essa opinião.

Há sérios aspectos legais a serem contemplados nestas discussões que demandam tempo e formação de apoio político, especialmente quando envolverem a necessidade de uma reforma constitucional, como é o caso da Lei de Anistia. Mas há também, certo entendimento na sociedade de que este não é um tema tão relevante, o que acaba fortalecendo o comportamento militar de vetar qualquer discussão mais séria sobre o assunto no âmbito do governo.

Para alguns, a continuação dos "escrachos" e o acúmulo de provas que a Comissão vier a criar, poderão levar a uma compreensão na sociedade de que a "evidente necessidade da memória", mencionada pelo personagem do filme Hirosima, meu amor, venha a criar a evidente necessidade de justiça.

\section{A judicialização e o fortalecimento da Lei de Anistia}

Desde o fim da ditadura, as iniciativas com vistas a julgamentos ocorreram em duas frentes: no Judiciário nacional, e no Sistema Inter-Americano de Justiça. Houve manifestos de juristas, pronunciamentos de ministros do STF e do Executivo. A União, por sua vez, defendeu a Lei de Anistia e os presidentes da República sempre adotaram a tese de que o assunto deveria estar afeito ao Poder Judiciário. Foi uma estratégia para evitar tensões e, ao mesmo tempo, manter um padrão errático de autonomia militar em temas de interesse corporativo.

Parte da oposição entende realisticamente que a anistia recíproca foi à época da promulgação da Lei de 1979 a forma possível de viabilizar a abertura. Mas entende também que justiça e leis devem ser entendidas como fatos dinâmicos. Assim, novos achados, novas concepções teóricas, permitiriam re-

44 KONRAD ADENAUER STIFTUNG. Los militares en la Europa del siglo XXI. Santiago do Chile: Konrad Adenauer Stiftung, 2004; MARTINEZ, Rafael e TULCHIN, Joseph S. (orgs.). La seguridad desde las orillas: un debate entre Europa e Latinoamérica. Barcelona: CIDOB, 2006. 
tornar ao passado com visões e instrumentos diferenciados.

A Comissão Interamericana dos Direitos Humanos da Organização dos Estados Americanos, OEA, em várias ocasiões foi acionada pelo Center for Justice and International Law (Cejil), por organizações de direitos humanos e até mesmo por órgãos do Executivo. Todos questionaram a posição do governo brasileiro pela omissão na investigação e punição de agentes do Estado envolvidos com a prática de tortura contra ativistas políticos durante o regime militar. ${ }^{45}$ Foi isso o que ocorreu, por exemplo, nos casos de guerrilheiros do Araguaia e na morte do jornalista Wladimir Herzog. Em ambos os casos o Brasil foi notificado a tomar providências, e nos dois respondeu que estava impedido de fazê-lo, dado que a Lei de Anistia impedia a abertura desse tipo de ação criminal.

No âmbito nacional houve, especialmente a partir de 2008, um movimento de processos em massa na Justiça, para pressionar o Judiciário a rever suas posições sobre a Lei de Anistia. ${ }^{46} \mathrm{O}$ juiz espanhol Baltazar Garzón, mundialmente famoso por ter conseguindo a prisão do ditador chileno Augusto Pinochet, visitou o país na ocasião, e referendou a posição de que leis de anistia locais não poderiam traçar limites à revelação de crimes contra a humanidade. ${ }^{47}$

O destino dos processos não variou muito. No caso das ações de responsabilização pelas mortes dos jornalistas Luiz Eduardo Merlino e Wladimir Herzog, a Justiça de São Paulo extinguiu os processos. Nas ações criminais e declaratórias contra os coronéis reformados Carlos Alberto Brilhante Ustra e Audir Santos Maciel, comandantes do DOI-CODI paulista nos anos 70, a Advocacia Geral da União (AGU), na voz de seu titular, José Antônio Dias Toffoli, assumiu a defesa dos acusados, alegando estarem protegidos pela Lei da Anistia de1979. ${ }^{48}$

A última inovação jurídica para contornar a Lei de Anistia, e permitir o julgamento e a responsabilização penal em caso de seqüestro, aguarda julgamento no STF no momento em que encerramos o trabalho. Será surpresa se essa Corte tiver posição diferente da que adotou até então. Foi com base na ideia de que crime de sequestro não se consome enquanto não houver o paradeiro da pessoa seqüestrada, que países como o Chile e o Uruguai conseguiram abrir ações criminais contra governantes e outros responsáveis por crimes contra os direitos humanos.

45 Jornal do Brasil Online, 27 de outubro de 2008.

46 Ver $O$ Globo, 28 d fevereiro de 2009.

47 Folha de São Paulo Online, 19 de agosto de 2008.

48 José Antônio Dias Toffoli, em 2009, foi nomeado ministro do STF. 


\section{Notas finais}

Depois da Lei da Anistia de 1979, não houve envolvimento explícito de partidos políticos ou do Congresso em relação à revisão do tema. 0 debate mobilizou timidamente a sociedade e o Parlamento, fortalecendo a capacidade organizada dos militares para manter intactos certos pontos relativos à memória. Provocou algumas fissuras dentro do governo, colocou ministros em lados opostos, mas mostrou, principalmente, a dificuldade de todos os governos civis em lidar com um tema considerado tabu pelas Forças Armadas.

Isso nos leva a pensar de onde os militares extraem tanta força. 0 prestígio e o poder de barganha de uma instituição são construídos e legitimados pelo tempo, mas especialmente pela relação estabelecida com a sociedade. ${ }^{49}$ As relações civil-militares são uma rota de mão dupla. Não haverá autonomia ou prestígio militar, se a sociedade não o consentir.

No caso do Brasil, o histórico protagonismo militar na política ficou no passado, mas algumas prerrogativas são social e legalmente consentidas. A reverência ou a cerimônia com que os governantes lidaram com os temas militares desde a redemocratização mostram esse legado histórico. Evidenciam também certa fragilidade democrática e, talvez, o trauma nacional em relação a intervenções armadas.

Direita e esquerdas no Brasil sempre cortejaram os quartéis e, por conseqüência, sempre desejaram e temeram a ação das Forças Armadas na política, dependendo para que lado pendessem. A ditadura recebeu amplo apoio social, e até hoje grande parte da sociedade lembra uma hipotética época de ouro, em que o país teria realizado um milagre econômico. A ação militar no combate à violência também é vista pela sociedade de maneira bastante positiva. Em meio a isso, a cultura de direitos humanos ainda é precária, e os valores éticos na política e na economia nos colocam num patamar vergonhoso nos rankings internacionais.

Construímos e mantivemos relações civil-militares duradouras em seus aspectos de autonomia e poder de barganha que combinam com baixa qualidade da democracia, com privilégios e com impunidade. A herança cultural não condena nenhuma sociedade ao fracasso ou ao sucesso, mas o temor em reformar ou criar instituições pode manter padrões que prejudiquem não apenas a democracia como a boa governança.

Um rigoroso balanço da posição da imprensa brasileira em relação à Comissão da Verdade desde sua criação em novembro de 2011, atesta que a posição majoritária é contra suas atividades. Alega-se a necessidade de paci-

49 O autor clássico é HUNTINGTON, Samuel P. O soldado e o Estado: teoria e política das relações entre civis e militares. Rio de Janeiro: Biblioteca do Exército, 1996. 
ficação, de esquecimento, a tradição conciliatória do país, nossa capacidade de "virar a página". Denotam-se ainda certos temores: pode ser um risco ao processo democrático, feridas serão inutilmente abertas, incertezas e desordens podem ser geradas. Não raro a Comissão é tratada como ação extemporânea, desprovida de sentido prático, e movida por ação raivosa. Para os que a defendem, em geral a expectativa é baixa. ${ }^{50}$

Como nos ensina Putnam, o país ainda permanece num círculo vicioso em que limitações do passado justificam a manutenção de vícios do presente. ${ }^{51}$ 0 mesmo autor ensina que mudar a história e a cultura é possível, ainda que demorado. Estamos longe de completar o caminho apontado pelas teorias da justiça de transição e o país tenta, com contradições, reverter a cultura de impunidade em relação aos crimes da ditadura. A Comissão Nacional da Verdade caminha nessa direção. A mesma "prática da verdade" e de condenação da impunidade é esperada em outras esferas da ação individual e governamental, particularmente entre nossas elites, mesmo depois da ditadura. Assim, apostando na revisão do passado, a Comissão pode também investir no futuro. Todavia, nenhum passo seguro será dado nessa direção, se algum ator na sociedade ou na política tiver poder de veto para suspender o debate ou gozar de privilégios que o colocam acima da lei.

50 Um levantamento rigoroso está sendo feito pela autora nos principais jornais do país.

51 PUTNAM, Robert. Comunidade e democracia: a experiência da Itália moderna. Rio de Janeiro: Editora FGV, 2005 . 